\title{
Article \\ Herbicide-Resistant Invasive Plant Species Ludwigia decurrens Walter
}

\author{
Denny Kurniadie ${ }^{1, *}$, Ryan Widianto ${ }^{1}$, Dedi Widayat ${ }^{1}$, Uum Umiyati ${ }^{1}$, Ceppy Nasahi ${ }^{2}$ \\ and Hisashi Kato-Noguchi ${ }^{3, * \mathbb{D}}$
}

1 Department of Agronomy, Faculty of Agriculture, Universitas Padjadjaran, Jl. Raya, Bandung Sumedang Km 21, Jatinangor, Sumedang 45363, Jawa Barat, Indonesia; ryanwidianto21@hotmail.com (R.W.); widayatdedi@yahoo.com (D.W.); umiyati_uum@yahoo.com (U.U.)

2 Department of Plant Pest and Diseases, Faculty of Agriculture, Universitas Padjadjaran, Jl. Raya, Bandung Sumedang Km 21, Jatinangor, Sumedang 45363, Jawa Barat, Indonesia; ceppynasahi@yahoo.com

3 Department of Applied Biological Science, Faculty of Agriculture, Kagawa University, Miki, Kagawa 761-0795, Japan

* Correspondence: denny.kurniadie@gmail.com (D.K.); kato.hisashi@kagawa-u.ac.jp (H.K.-N.)

\section{check for} updates

Citation: Kurniadie, D.; Widianto, R.; Widayat, D.; Umiyati, U.; Nasahi, C.; Kato-Noguchi, $\mathrm{H}$.

Herbicide-Resistant Invasive Plant Species Ludwigia decurrens Walter. Plants 2021, 10, 1973. https:// doi.org/10.3390/plants10091973

Academic Editors:

Anastasia Christopoulou,

Ioannis Bazos, Andreas Zikos and Hugh J. Beckie

Received: 28 June 2021

Accepted: 16 September 2021

Published: 21 September 2021

Publisher's Note: MDPI stays neutral with regard to jurisdictional claims in published maps and institutional affiliations.

Copyright: (C) 2021 by the authors. Licensee MDPI, Basel, Switzerland. This article is an open access article distributed under the terms and conditions of the Creative Commons Attribution (CC BY) license (https:/ / creativecommons.org/licenses/by/ $4.0 /)$.

\begin{abstract}
Ludwigia decurrens Walter is a dicotyledonous plant belonging to the family Onagraceae. It is native to Central Eastern USA but has been spreading quickly and has naturalized in aquatic and riparian ecosystems (including rice paddy fields) in many countries; therefore, it is now considered an invasive noxious weed. L. decurrens is highly competitive with rice and causes a significant reduction in rice production. The objective of the present study was to evaluate the efficacy of the herbicide penoxsulam for the control of $L$. decurrens in rice fields. The seeds of $L$. decurrens were collected from four villages in Indonesia, and penoxsulam was applied to $L$. decurrens in seven dosages $(0,2.5,5,10$, 20, 40, and $80 \mathrm{~g}$ a.i. ha $\left.{ }^{-1}\right) 3$ weeks after seed sowing. The plant populations from Hegarmanah, Jatisari, and Joho showed complete mortality at the recommended dosage of penoxsulam $\left(10 \mathrm{~g}\right.$ a.i. ha $\left.{ }^{-1}\right)$. However, the plants from Demakan grew, flowered, and produced seeds 56 days after treatment with $40 \mathrm{~g}$ a.i. $\mathrm{ha}^{-1}$ of penoxsulam. The resistance index value of the population was 36.06 . This is the first report of a penoxsulam-resistant weed from a dicotyledonous plant species and also the first report of a herbicide-resistant population of L. decurrens. The appearance of herbicide-resistant L. decurrens is a serious issue from both an environmental and an economic perspective, especially since protected forest and freshwater ecosystems are located at a short distance from the study area. Further research is needed to evaluate herbicide mixtures and/or the rotation of herbicide action sites. The identification of the penoxsulam-resistance mechanism in L. decurrens is also necessary to develop a herbicide resistance management strategy.
\end{abstract}

Keywords: herbicide resistance; invasive; Ludwigia decurrens; penoxsulam; rice weed

\section{Introduction}

Ludwigia decurrens Walter, belonging to the Onagraceae family, is a synonym of Jussiaea decurrens Walter D.C. It is an annual or woody perennial herb that stands upright reaching $2 \mathrm{~m}$ of height, with alternate branches. The leaves are opposite, narrowly elliptical, 4-12 cm long, and 1-3 cm wide. A single flower with four bright yellow petals is produced in the upper leaf axis. A seed capsule develops immediately below the flower and contains up to 1000 seeds per capsule [1-3]. The species grows in wetlands including paddy fields, riverbanks, ponds, and slow-moving streams $[1,4]$. It has adapted to these aquatic habitats through the development of rhizomes with aerenchyma [5].

L. decurrens is native to Central Eastern USA but has been introduced accidentally into many countries in South and East Asia and Africa, where it is now considered an invasive noxious weed $[1,2,4,6,7]$. It produces a large number of seeds and spreads rapidly in the wet zone through seeds and plant fragments floating on water $[1,4,8]$. It has also allelopathic 
properties. The exudates of the plants inhibited the growth of Corchorus olitorius L. and increased its mortality [9]. Allelopathy may also be involved in L. decurrens invasion [10-12]. The severe invasion of some plant species often causes a significant reduction of biodiversity in the invaded ecosystems $[13,14]$. The risk of a negative environmental impact for L. decurrens is high because of its pest dispersal potential [4].

L. decurrens emerges along with rice seedlings and grows in rice paddy fields. It is highly competitive with rice due to its fast growth rate and a life cycle similar to that of rice and causes a significant reduction in rice production [1,15]. L. decurrens suppresses the development of tillers, panicles, leaves, and spikelets of rice plants. Consequently, the risk of an economic impact due to lower crop yields and quality is high [4]. For example, L. decurrens has been reported to reduce rice grain yield by around 30\% [15]. Penoxsulam is one of the pre-emergence herbicides widely used in rice cultivation [16]. It is an acetolactate synthase (ALS; EC 4.6.3.8) inhibitor and is an efficient broad-spectrum herbicide against grass and broadleaf weeds [17]. This herbicide has been effective in controlling L. decurrens. However, excessive application of herbicides increases the potential to develop resistant weeds [18-20]. The appearance of herbicide-resistant weeds was predicted by Harper in 1956 [21], and a herbicide resistant-weed was first observed in sugarcane plantations in Hawaii [22]. Following this, triazine-resistant Senecio vulgaris L. [23] and 2,4-D-resistant Convolvulus arvensis L. [24] were recorded. Currently, 264 herbicide-resistant weed species522 cases (species $\times$ site of action) for 164 herbicides-have been reported in 94 crops in 71 countries [25]. The present study was conducted due to reports of L. decurrens becoming difficult to control in rice paddy fields of Central Java, Indonesia. The efficiency of penoxsulam on L. decurrens collected from four Central Java villages was evaluated, and a penoxsulam-resistant $L$. decurrens population was confirmed for the first time.

\section{Materials and Methods}

\subsection{Plant Materials}

Four locations (lowland rice cultivation areas) were selected for L. decurrens seed collection; (1) Jatisari village (Jatisari District, Karawang Regency, West Java Province; $\left.6^{\circ} 22^{\prime} 41.8^{\prime \prime} \mathrm{S}, 107^{\circ} 31^{\prime} 42.1^{\prime \prime} \mathrm{E}\right)$, (2) Joho village (Mojolaban District, Sukoharjo Regency, Central Java Province; $7^{\circ} 35^{\prime} 25.2^{\prime \prime} \mathrm{S}, 110^{\circ} 53^{\prime} 39.7^{\prime \prime} \mathrm{E}$ ), (3) Demakan village (Mojolaban District, Sukoharjo Regency, Central Java Province; $7^{\circ} 41^{\prime} 19.5^{\prime \prime}$ S, $110^{\circ} 49^{\prime} 58.0^{\prime \prime}$ E), and (4) Hegarmanah village (Jatinangor District, Sumedang Regency, West Java Province; $6^{\circ} 54^{\prime} 50.1^{\prime \prime} \mathrm{S}, 107^{\circ} 46^{\prime} 20.1^{\prime \prime} \mathrm{E}$ ). At each location, seeds were collected from several plants in August 2020 and mixed well. The seeds were then cleaned and dried in the sun for one week to reduce the moisture and increase the maturity of the seeds.

\subsection{Penoxsulam Dose-Response Experiment}

Penoxsulam dose-response experiments were carried out using the whole-plant pot test dose-response method [26]. Pots $(20 \mathrm{~cm}$ in diameter) were filled with paddy soil after sterilization using an autoclave at $120^{\circ} \mathrm{C}$ and 15 Psi for $2 \mathrm{~h}$ so that only L. decurrens seeds were allowed to germinate and grow. Then, 10-20 seeds of $L$. decurrens were sowed on the soil surface in the pots. Water was applied regularly, and the water level was maintained at $0.5 \mathrm{~cm}$ above the soil surface to keep an adequate amount of water in the soil during the experiments. Three weeks after sowing, plants grew approximately $10 \mathrm{~mm}$ in height with two leaves, and penoxsulam (Clipper 25 OD, $25 \mathrm{~g} \mathrm{~L}^{-1}$, Dow Agro Science Indonesia) was applied at 7 dosages $\left(0,2.5,5,10,20,40\right.$, and $80 \mathrm{~g}$ a.i. ha $\left.{ }^{-1}\right)$ by using a semi-automatic knapsack sprayer with a flat fan nozzle at a pressure of $138 \mathrm{kPa}$. The recommended dosage of the herbicide is $10 \mathrm{~g}$ a.i. $\mathrm{ha}^{-1}$. After 28 days from herbicide application, L. decurrens was harvested, except for one plant per pot. Five plants among the harvested plants for each treatment were used for the determination of their dry weight. The remaining plant was grown for 56 days after herbicide application. 


\subsection{Statistical Analysis}

The experimental design used in this experiment was a 2-factor split plot (main factor; populations, subfactor; penoxsulam dosage) with three replications. The percentage of weed damage was obtained from the comparison between the dry weight of herbicidetreated weeds $(\mathrm{T})$ and the dry weight of control weeds, which were not treated with the herbicide (C), using the following equation (1) [27]:

$$
\text { Percentage of damage }(\%)=[1-(\mathrm{T} / \mathrm{C})] \times 100
$$

The percentage of damage was analyzed by ANOVA. The interaction between weed populations and herbicide doses was analyzed based on a $p$-value $<0.05$. If an interaction occurred, Tukey's test was used to identify significant differences.

The penoxsulam dose required for $50 \%$ growth reduction $\left(\mathrm{GR}_{50}\right)$ was obtained by nonlinear regression using the log-logistic dose response equation (2) as described in [28]:

$$
\mathrm{Y}=\mathrm{c}+(\mathrm{d}-\mathrm{c}) /\left[1+\left(\mathrm{X} / \mathrm{GR}_{50}\right)^{\mathrm{b}}\right]
$$

where $\mathrm{Y}$ represents dry weight at herbicide dose $(X)$, whereas $\mathrm{c}$ and $\mathrm{d}$ denote lower and upper limits, respectively, and $\mathrm{b}$ is the slope of the response curve. The dose-response analysis was performed using OriginPro 9.0.

\section{Results}

The recommended dosage of penoxsulam (10 g a.i. ha $\left.{ }^{-1}\right)$ controlled $100 \%$ of L. decurrens populations obtained from Hegarmanah, Jatisari, and Joho villages. However, the damage to the population from Demakan village was $38.24 \%$ and $72.85 \%$ at the recommended dosage and at the four-fold recommended dosage of $40 \mathrm{~g}$ a.i. ha ${ }^{-1}$, respectively (Table 1). The populations of Hegarmanah, Jatisari, and Joho showed complete mortality at the recommended dosage of penoxsulam (Figure 1). The plants of the Demakan population grew and produced flowers, and seeds were obtained 56 days after the treatment with penoxsulam (Figure 2).

Table 1. Effect of penoxsulam on the percentage of damage to L. decurrens.

\begin{tabular}{cccccccc}
\hline \multirow{2}{*}{ Population } & \multicolumn{7}{c}{ Penoxsulam Dosage (g a.i. ha ${ }^{-\mathbf{1}}$ ) } \\
\cline { 2 - 8 } & $\mathbf{0}$ & $\mathbf{2 . 5}$ & $\mathbf{5}$ & $\mathbf{1 0}$ & $\mathbf{1 0}$ & $\mathbf{4 0}$ & $\mathbf{8 0}$ \\
\hline Hegarmanah & $0 \mathrm{a}, \mathrm{A}$ & $89.18 \mathrm{a}, \mathrm{B}$ & $92.22 \mathrm{a}, \mathrm{B}$ & $100 \mathrm{a}, \mathrm{B}$ & $100 \mathrm{a}, \mathrm{B}$ & $100 \mathrm{a}, \mathrm{B}$ & $100 \mathrm{a}, \mathrm{B}$ \\
Jatisari & $0 \mathrm{a}, \mathrm{A}$ & $87.22 \mathrm{a}, \mathrm{B}$ & $92.17 \mathrm{a}, \mathrm{B}$ & $100 \mathrm{a}, \mathrm{B}$ & $100 \mathrm{a}, \mathrm{B}$ & $100 \mathrm{a}, \mathrm{B}$ & $100 \mathrm{a}, \mathrm{B}$ \\
Joho & $0 \mathrm{a}, \mathrm{A}$ & $82.53 \mathrm{~b}, \mathrm{~B}$ & $92.23 \mathrm{a}, \mathrm{C}$ & $100 \mathrm{a}, \mathrm{C}$ & $100 \mathrm{a}, \mathrm{C}$ & $100 \mathrm{a}, \mathrm{C}$ & $100 \mathrm{a}, \mathrm{C}$ \\
Demakan & $0 \mathrm{a}, \mathrm{A}$ & $20.11 \mathrm{c}, \mathrm{B}$ & $37.57 \mathrm{~b}, \mathrm{C}$ & $38.24 \mathrm{~b}, \mathrm{C}$ & $51.2 \mathrm{~b}, \mathrm{D}$ & $72.85 \mathrm{~b}, \mathrm{E}$ & $100 \mathrm{a}, \mathrm{F}$ \\
\hline
\end{tabular}

The percentage of damage was calculated from the comparison between the dry weight of herbicide-treated L. decurrens and that of control L. decurrens. Damage of $100 \%$ indicates complete inhibition. Values in each column followed by the same lowercase letters (vertical direction) and uppercase letters (horizontal direction) are not significantly different at $p<0.05$ according to the Tukey test.

The $\mathrm{GR}_{50}$ value of penoxsulam for the Hegarmanah population was $0.63 \mathrm{~g}$ a.i. ha ${ }^{-1}$ (Figure 3, Table 2). As reported when interviewed, farmers of Hegarmanah village have never used any herbicides. Other farmers of Jatisari, Joho, and Demakan villages have applied penoxsulam twice per rice growing season ( 7 days and 21 days after planting), with three rice cultivations per year over the last 10 years. Therefore, the level of the resistance index (R/S) for penoxsulam was calculated by the ratio of the $\mathrm{GR}_{50}$ value of the Hegarmanah population ( $S$; susceptible) to those of the other three populations (R; resistant), and the plants were classified as susceptible $(R / S<2)$, low-resistance $(R / S=2-6)$, moderateresistance $(R / S=6-12)$, and high-resistance $(R / S ~>12)$ [29]. The $R / S$ index of Demakan was 36.06, which indicates that the resistance of Demakan to penoxsulam was 36.06-fold greater than that of Hegarmanah (Table 2). Therefore, the efficiency of penoxsulam against the Demakan population was very low, and the population was classified as resistant, whereas the Jatisari and Joho populations were classified as susceptible because their R/S was less than 2 . 


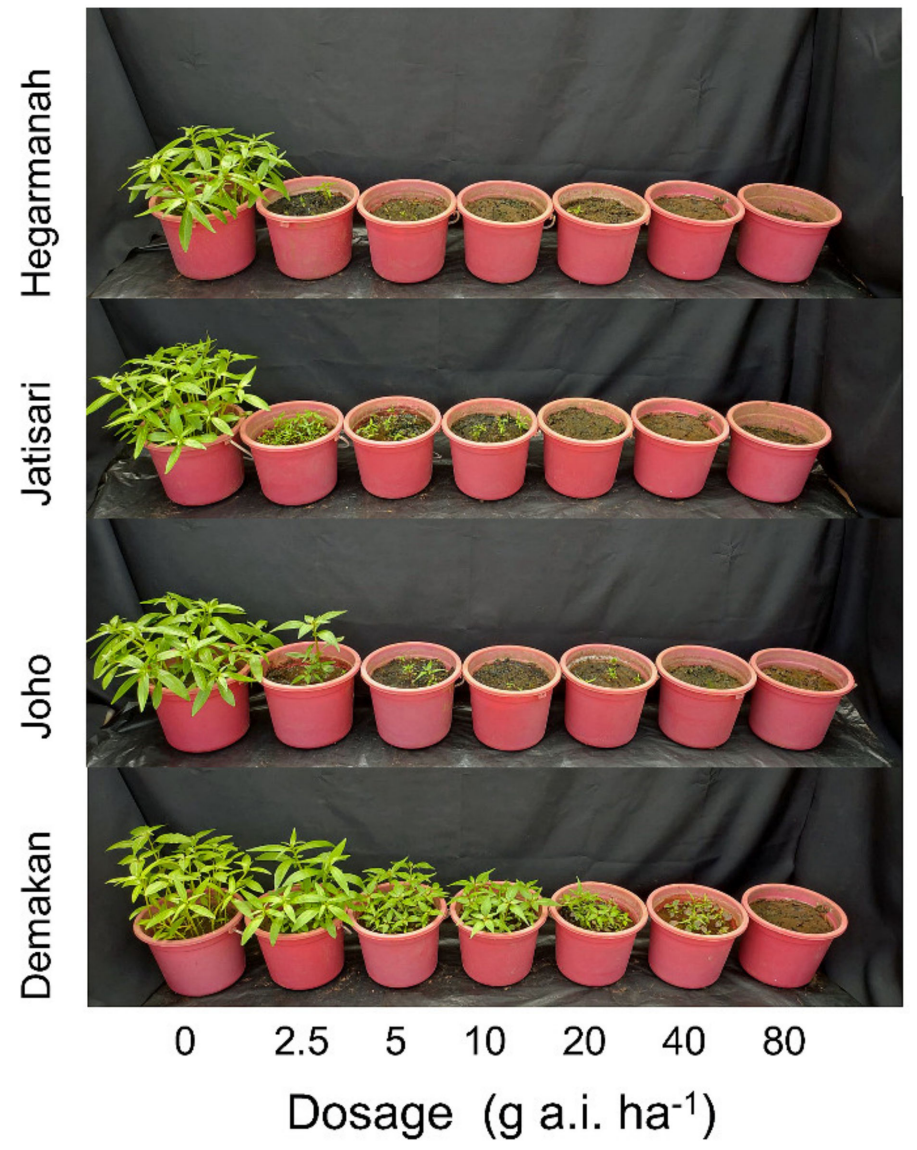

Figure 1. Effect of penoxsulam on four populations of L. decurrens 28 days after herbicide application.

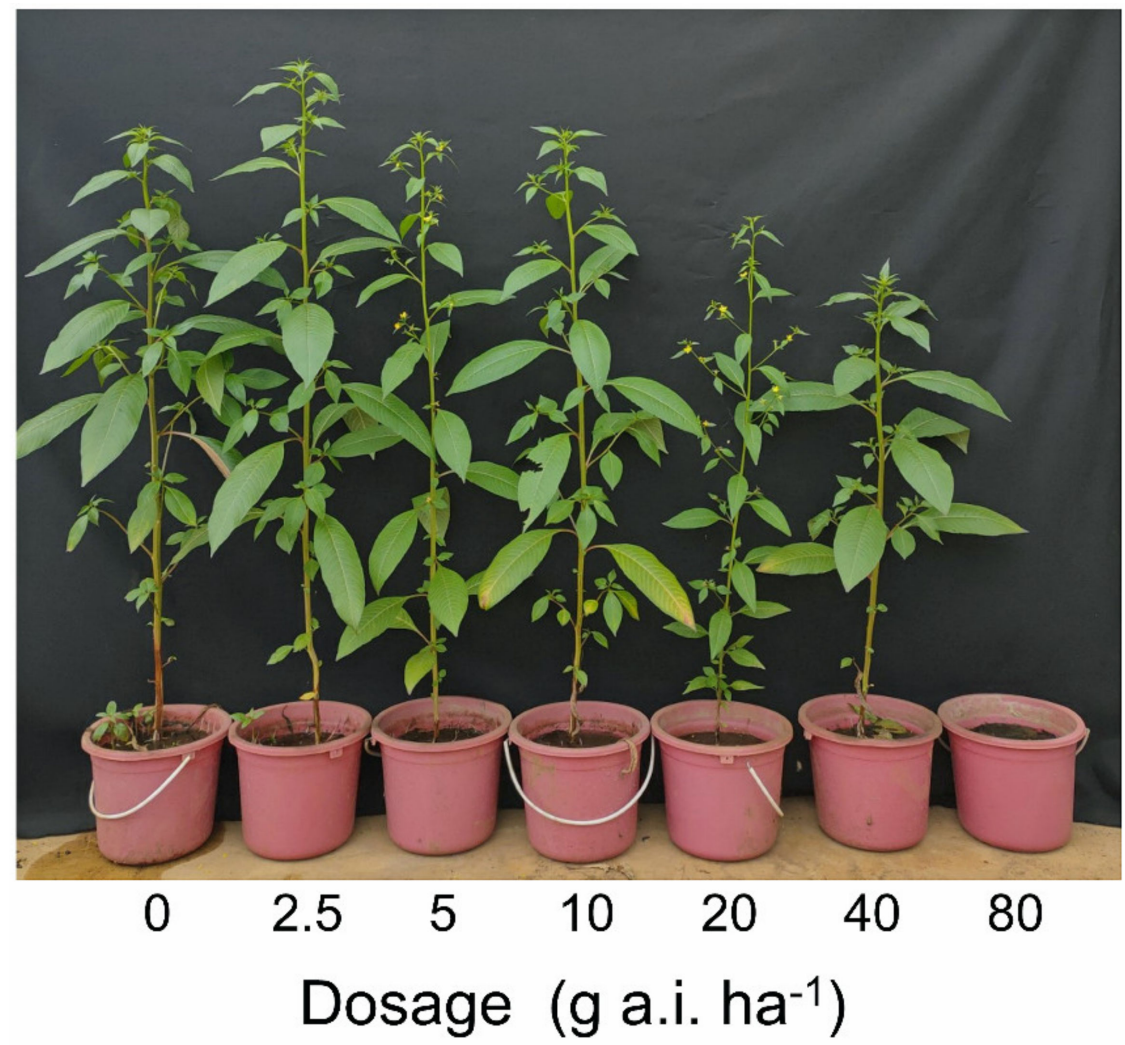

Figure 2. Effect of penoxsulam on the Demakan population of L. decurrens 56 days after herbicide application. 


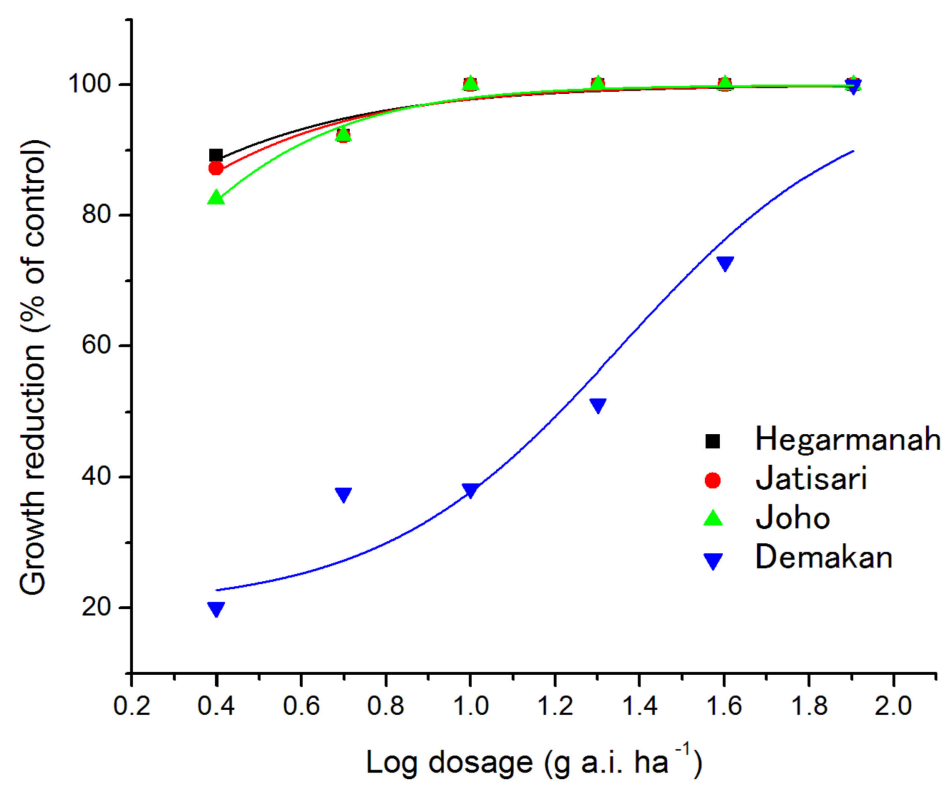

Figure 3. Growth reduction curves of four populations of L. decurrens against penoxsulam dose.

Table 2. Herbicide dose required for $50 \%$ reduction $\left(\mathrm{GR}_{50}\right)$ of dry biomass and resistance index.

\begin{tabular}{cccccccc}
\hline Population & $\mathbf{c}$ & $\mathbf{d}$ & $\mathbf{b}$ & $\mathbf{r}^{\mathbf{2}}$ & $\begin{array}{c}\mathbf{G R}_{\mathbf{5 0}} \\
\left.\text { (g a.i. ha } \mathbf{~}^{-1}\right)\end{array}$ & $\begin{array}{c}\text { Resistance } \\
\text { Index }\end{array}$ & $\begin{array}{c}\text { Level of } \\
\text { Resistance }\end{array}$ \\
\hline Hegarmanah & 20.11 & 100 & 1.29 & 0.86 & 0.63 & - & - \\
Jatisari & 20.11 & 100 & 1.42 & 0.91 & 0.81 & 1.28 & Susceptible \\
Joho & 20.11 & 100 & 1.75 & 0.97 & 1.23 & 1.95 & Susceptible \\
Demakan & 20.11 & 100 & 1.53 & 0.92 & 22.72 & 36.06 & Resistance \\
\hline
\end{tabular}

$\mathrm{GR}_{50}$ values of penoxsulam were obtained by nonlinear regression using the log-logistic dose-response equation. The resistance index against penoxsulam was calculated by the ratio of the $\mathrm{GR}_{50}$ value of the Hegarmanah population to those of the other three populations.

\section{Discussion}

An invasive plant species, $L$. decurrens, has been spreading quickly and naturalized into aquatic and riparian ecosystems including rice paddy fields in many countries $[1,2,4,6,7]$. This species has been reported to occupy $50 \%$ of the invaded plant community, and thus is considered one of the most aggressive weed species [3,8]. Consequently, the risks associated with L. decurrens invasion are high from both an environmental and an economic perspective [4]. Management of L. decurrens relies on physical and chemical methods [30], and penoxsulam has effectively controlled L. decurrens so far. However, we identified penoxsulam-resistant $L$. decurrens plants from a Demakan population for the first time in this study (Figure 1, Table 1). The resistance index value of the population was 36.06 (Table 2), and the plants made flowers and produced seeds (Figure 2).

The possibility of the herbicide-resistant $L$. decurrens to spread and dominate in the surrounding area may be high because of the properties of the species $[3,8]$. The total area of rice paddy fields is 20,460 ha in the Sukoharjo regency, which the Demakan village belongs to [31]. In addition, the protected forest Gunung Merbabu and the Gajah Mungkur water reservoir are located 20 and $50 \mathrm{~km}$ from the study area of the Demakan village, respectively. L. decurrens has been recorded to spread up to $120 \mathrm{~km}$ through seeds and plant fragments floating on water [32]. Therefore, the appearance of herbicide-resistant L. decurrens could be a possible threat for the nearby protected areas.

The excess application of herbicides with a single mode of action increases the risk of causing gene mutations leading to the appearance of herbicide-resistant weeds. Many other factors, such as cropping system, weed potentiality, and environment, also increase the appearance of resistant weeds [18-20]. Echinochloa crus-galli (L.) P.Beauv. is one of the most dangerous weeds in crop production and is mainly controlled by herbicides $[25,33,34]$. 
Continuous and excess applications of herbicides such as ALS-inhibiting and acetyl-CoA carboxylase (ACCase; E.C.6.4.1.2)-inhibiting herbicides have originated multiple-herbicideresistant $E$. crus-galli populations [25,33-37].

ALS is the enzyme in the biosynthetic pathway of the branched-chain amino acids valine, leucine, and isoleucine [38]. ALS is an important target site for at least four structurally distinct classes of herbicides, i.e., sulfonylureas [39,40], imidazolinones [41], triazolopyrimidines [42], and pyrimidinylsalicylates [43]. The ALS inhibitor penoxsulam has become the most widely used herbicide in rice cultivation since its introduction $[16,37]$. There have been 103 cases of weed resistance to ALS herbicides in rice cultivation [18,25]. Limnocharis flava (L.) Buchenau from Malaysia's Penang Island was found to be resistant to several ALS enzyme-inhibiting herbicides, such as the sulfonylurea and imidazolinone herbicide groups. Monochoria vaginalis (Burm.f.) Kunth from rice fields with an intensive use of herbicides in Chonnam, Korea, was resistant to the sulfonylurea and pyrimidinylsalicylate groups. Therefore, some ALS herbicide-resistant weed species showed resistance to multiple herbicides $[18,25]$. Based on the data from herbicide-resistant weed species, 7 penoxsulam resistantweed species with 19 cases have been reported: Echinochloa crus-galli, Echinochloa oryzicola Vasing., Cyperus iria L., Cyperus difformis L., Cyperus esculentus L., Fimbristylis miliacea (L.) Vahl., and Sagittaria montevidensis Cham. \& Schltdl. Of the 19 penoxsulam resistance cases, 17 experienced cross or multiple resistance [25]. All penoxsulam-resistant weed species reported belong to monocotyledonous plant species, and Echinochloa crus-galli was the most frequently reported. Ours is the first report of a penoxsulam-resistant weed from dicotyledonous plant species and also the first report of a herbicide-resistant population of L. decurrens [25].

According to Heap [18,25], there are five primary mechanisms of herbicide resistance: (1) target-site resistance, (2) enhanced metabolism of herbicides, (3) decreased absorption and translocation of herbicides, (4) sequestration of herbicides, and (5) gene amplification of target genes. Resistance to ALS inhibitors, ACCase inhibitors, triazine and dinitroaniline herbicides is often caused by target-site resistance mechanism. Target-site resistance may be caused by gene mutations that modify the herbicide binding site, inhibiting herbicide binding $[18,37]$. Mutations in ALS inhibitors have been reported in the amino acids $\mathrm{Thr}_{102}$ (four cases), $\mathrm{Ala}_{103}$ (one case), and $\mathrm{Pro}_{103}$ (21 cases) of the ALS protein (the amino acid number is standardized according to the sequence of the ALS protein in Arabidopsis thaliana (L.) Heynh.) in various weed species [25]. The high frequency of herbicide application can increase the possibility of gene mutations that modify the herbicide binding sites $[18,37]$. As describe earlier, farmers of Demakan villages applied penoxsulam twice during each rice growing season with three rice cultivations per year for over 10 years, without herbicide rotation. Therefore, it is possible that penoxsulam resistance in L. decurrens may have been caused by mutations leading to the modification of the herbicide binding sites, causing target-site resistance.

The appearance of resistance to multiple herbicides in weeds is a serious issue for weed control. In fact, populations of Lolium rigidum Gaud. were found to be resistant in seven herbicide action sites [18,25,44]. Populations of Amaranthus palmeri S.Wats. showed resistance to PSII inhibitors, ALS inhibitors, ACCase inhibitors, 4-HPPD inhibitors, glyphosate, and others $[18,25]$. Population of Ludwigia prostrata Roxb., which belongs to the same genus of $L$. decurrens, from South Korea, showed multiple resistance to ALS inhibitor herbicides, such as sulfonylureas, imidazolinones, and pyrimidinylsalicylates [18,25]. Therefore, further investigation of resistance to multiple herbicides in L. decurrens is necessary.

The most common herbicide resistance management strategy may be to rotate herbicide action sites $[45,46]$. This practice may delay the evolution of herbicide resistance. The employment of herbicide mixtures, such as combinations of ALS inhibitors, ACCase inhibitors, glyphosate, glufosinate, 4-HPPD inhibitors, and synthetic auxins may also delay the appearance of resistance. However, it is essential to identify the penoxsulam resistance mechanism in L. decurrens to design an efficient herbicide resistance management strategy. 


\section{Conclusions}

L. decurrens, originated from Central Eastern USA, has naturalized in many countries as a noxious invasive weed species in aquatic and riparian ecosystems including rice paddy fields. The ALS inhibitor herbicide penoxsulam has effectively controlled $L$. decurrens so far. However, a penoxsulam-resistant population was identified in Central Java, Indonesia, which is close to protected areas. Its resistance index value was 36.06 . These resistant plants grew, flowered, and produced seeds 56 days after treatment with $40 \mathrm{~g}$ a.i. ha ${ }^{-1}$ of penoxsulam, a dose four-fold greater than the recommended one. The farmers in the area applied penoxsulam twice per rice growing season with three rice cultivations per year over the last 10 years, without herbicide rotation. Therefore, it is possible that the penoxsulam-resistant $L$. decurrens emerged as a consequence of the modification of the herbicide binding sites in the enzyme. The employment of herbicide mixtures and/or the rotation of herbicide action sites should be considered. The identification of the penoxsulamresistant mechanism in L. decurrens is also necessary for an effective herbicide resistance management strategy.

Author Contributions: Conceptualization, D.K.; methodology, D.K., D.W. and U.U.; validation, D.K. and C.N.; investigation, D.K., R.W., D.W. and U.U.; resources, D.K. and C.N.; data curation, D.K., R.W., U.U. and C.N.; reviewing literatures, writing and editing, D.K. and H.K.-N.; project administration, D.K.; funding acquisition, D.K. All authors have read and agreed to the published version of the manuscript.

Funding: This research was funded by the Academic Leadership Grant Universitas Padjadjaran.

Institutional Review Statement: Not applicable.

Informed Consent Statement: Not applicable.

Data Availability Statement: No supporting data in this study.

Acknowledgments: We thank the Rector of the Universitas Padjadjaran for the scheme of the Academic Leadership Grant (ALG) for supporting the project.

Conflicts of Interest: The authors declare no conflict of interest.

\section{References}

1. Chandrasena, J.P.N.R. Ludwigia decurrens Walt. A new rice-field weed in Sri Lanka. J. Natl. Sci. Found. Sri Lanka 1988, 16, 97-103. [CrossRef]

2. Barua, I.C. The genus Ludwigia (Onagraceae) in India. Rheedea 2010, 20, 59-70.

3. USDA; NCRS. Plant Guide. Willow Primrose. Available online: https://plants.sc.egov.usda.gov/home/plantProfile?symbol= LUDE4 (accessed on 2 May 2021).

4. Tag Archives; Ludwigia Decurrens (Winged Water-Primrose). Available online: https://blogs.cdfa.ca.gov/Section3162/?tag= ludwigia-decurrens (accessed on 2 May 2021).

5. Bedoya, A.M.; Madriñán, S. Evolution of the aquatic habit in Ludwigia (Onagraceae): Morpho-anatomical adaptive strategies in the Neotropics. Aquat. Bot. 2015, 120 Pt B, 352-362. [CrossRef]

6. Oyedeji, O.; Oziegbe, M.; Taiwo, F.O. Antibacterial, antifungal and phytochemical analysis of crude extracts from the leaves of Ludwigia abyssinica A. Rich. and Ludwigia decurrens Walter. J. Med. Plants Res. 2011, 5, 1192-1199.

7. Kong, L.P.; Peng, Y.F.; You, K.; Peng, H.H.; Wang, G.H. Ludwigia decurrens Walt., a naturalized hydrophyte in mainland China. J. Trop. Subtrop. Bot. 2019, 27, 338-342.

8. Cronk, Q.C.B.; Fuller, J.L. Plant Invaders: The Threat to Natural Ecosystems; Earthscan Publications: London, UK, 2001; pp. 1-241.

9. Sakpere, A.M.; Oziegbe, M.; Bilesanmi, I.A. Allelopathic effects of Ludwigia decurrens and L. adscendens subsp. diffusa on germination, seedling growth and yield of Corchorus olitorius L. Not. Sci. Biol. 2010, 2, 75-80. [CrossRef]

10. Lockwood, J.L.; Simberloff, D.; McKinney, M.L.; Von Holle, B. How many, and which, plants will invade natural areas. Biol. Invasions 2001, 3, 1-8. [CrossRef]

11. Cappuccino, N.; Arnason, J.T. Novel chemistry of invasive exotic plants. Biol. Lett. 2006, 2, 189-193. [CrossRef]

12. Chengxu, W.; Mingxing, Z.; Xuhui, C.; Bo, Q. Review on allelopathy of exotic invasive plants. Procedia Eng. 2011, 18, $240-246$. [CrossRef]

13. Kumar, R.P.; Singh, J.S. Invasive alien plant species: Their impact on environment, ecosystem services and human health. Ecol. Indic. 2020, 111, 106020. [CrossRef] 
14. Langmaier, M.; Lapin, K. Systematic review of the impact of invasive alien plants on forest regeneration in European temperate forests. Front. Plant Sci. 2020, 113, 524969. [CrossRef]

15. Dharmaratne, P.G.; Ranamukaarachchi, S.L. Sensitivity of rice to Ludwigia decurrens (L.). Trop. Agric. Res. 1991, 3, $180-194$.

16. Larelle, D.; Mann, R.; Cavanna, S.; Bernes, R.; Duriatti, A.; Mavrotas, C. Penoxsulam, a new broad spectrum rice herbicide for weed control in European Union paddies. In Proceedings of the International Congress Crop Science and Technology, Glasgow, Scotland, UK, 10-12 November 2003; British Crop Protection Council: Farnham, UK, 2003; pp. 75-80.

17. Johnson, T.C.; Martin, T.P.; Mann, R.K.; Pobanz, M.A. Penoxsulam-structure-activity relationships of triazolopyrimidine sulfonamides. Bioorg. Med. Chem. 2009, 17, 4230-4240. [CrossRef] [PubMed]

18. Heap, I. Global perspective of herbicide-resistant weeds. Pest Manag. Sci. 2014, 70, 1306-1315. [CrossRef]

19. Baucom, R.S. Evolutionary and ecological insights from herbicide-resistant weeds: What have we learned about plant adaptation, and what is left to uncover? New Phytol. 2019, 223, 68-82. [CrossRef] [PubMed]

20. Moss, S.; Ulber, L.; Hoed, I.D. A herbicide resistance risk matrix. Crop Prot. 2019, 115, 13-19. [CrossRef]

21. Harper, J.L. The evolution of weeds in relation to resistance to herbicides. In Proceedings of the 3rd British Weed Control Conference, British Weed Control Council, Farnham, UK, 5-8 November 1956; pp. 179-188.

22. Hilton, H.W. Herbicide tolerant strains of weeds. In Hawaiian Sugar Planters Assocociation Annual Repport; University Press of Hawaii: Honolulu, HI, USA, 1957; pp. 69-72.

23. Ryan, G.F. Resistance of common groundsel to simazine and Atrazine. Weed Sci. 1970, 18, 614-616. [CrossRef]

24. Schweizer, E.E.; Swink, J.F. Field bindweed control with dicamba and 2,4-D, and crop response to chemical residues. Weed Sci. 1971, 19, 717-721. [CrossRef]

25. Heap, I. The International Herbicide-Resistant Weed Database. Available online: http:/ / www.weedscience.org (accessed on 2 May 2021).

26. Burgos, N.R. Whole-plant and seed bioassays for resistance confirmation. Weed Sci. 2015, 63, 152-165. [CrossRef]

27. Juraimi, A.S.; Begum, M.; Parvez, A.M.; Shari, E.S.; Sahid, I.; Man, A. Controlling resistant Limnocharis flava (L.) Buchenau biotype through herbicide mixture. J. Food Agric. Environ. 2012, 10, 1344-1348.

28. Seefeldt, S.S.; Jensen, J.E.; Feurst, E.P. Log-logistic analysis of herbicide dose-response relationships. Weed Technol. 1995, 9, $218-227$. [CrossRef]

29. Ahmad-Hamdani, M.S.; Owen, M.J.; Yu, Q.; Powles, S.B. ACCase-inhibiting herbicide-resistant Avena spp. Populations from the Western Australian grain belt. Weed Techn. 2012, 26, 130-136. [CrossRef]

30. Thouvenot, L.; Haury, J.; Thiébaut, G. A success story: Water primroses, aquatic plant pests. Aquat. Conserv. Mar. Freshw. Ecosyst. 2013, 23, 790-803. [CrossRef]

31. Statistical Bureau of Sukoharjo Regency. Available online: https://sukoharjokab.bps.go.id/indicator/153/80/1/luaspenggunaan-lahan.html (accessed on 24 June 2021).

32. Grewell, B.J.; Netherland, M.D.; Thomason, M.J.S. Establishing Research and Management Priorities for Invasive Water Primroses (Ludwigia spp.); U.S. Army Crops of Engineers: Washington, DC, USA, 2016; pp. 1-42.

33. Holm, L.G.; Plucknett, D.L.; Pancho, J.V.; Herberger, J.P. The World's Worst Weeds, Distribution and Biology; University Press of Hawaii: Honolulu, HI, USA, 1977; pp. 1-609.

34. Chen, G.; Wang, Q.; Yao, Z.; Zhu, L.; Dong, L. Penoxsulam-resistant barnyardgrass (Echinochloa crus-galli) in rice fields in China. Weed Biol. Manag. 2016, 16, 16-23. [CrossRef]

35. Riar, D.S.; Norsworthy, J.K.; Srivastava, V.; Nandula, V.; Bond, J.A.; Scott, R.C. Physiological and molecular basis of acetolactate synthase-inhibiting herbicide resistance in barnyardgrass (Echinochloa crus-galli). J. Agric. Food Chem. 2013, 61, 278-289. [CrossRef]

36. Matzenbacher, F.O.; Bortoly, E.D.; Kalsing, A.; Merotto, A. Distribution and analysis of the mechanisms of resistance of barnyardgrass (Echinochloa crus-galli) to imidazolinone and quinclorac herbicides. J. Agric. Sci. 2015, 153, 1044-1058. [CrossRef]

37. Fang, J.; Zhang, Y.; Liu, T.; Yan, B.; Li, J.; Dong, L. Target-site and metabolic resistance mechanisms to penoxsulam in barnyardgrass (Echinochloa crus-galli (L.) P. Beauv). J. Agric. Food Chem. 2019, 67, 8085-8095. [CrossRef]

38. Shimizu, T.; Nakayama, I.; Nagayama, K.; Miyazawa, T.; Nezu, Y. Acetolactate synthase inhibitors. In Herbicide Classes in Development; Böger, P., Wakabayashi, K., Hirai, K., Eds.; Springer: Berlin/Heidelberg, Germany, 2002; pp. 1-41.

39. LaRossa, R.A.; Van Dyk, T.K.; Smulski, D.R. Toxic accumulation of 2-ketobutyrate caused by inhibition of the branched-chain amino acid biosynthetic enzyme acetolactate synthase in Salmonella typhimurium. J. Bacteriol. 1987, 169, 1372-1378. [CrossRef]

40. Ray, T.B. Site of action of chlorsulfuron: Inhibition of valine and isoleucine biosynthesis in plants. Plant Physiol. 1984, 75, 827-831. [CrossRef]

41. Shaner, D.L.; Anderson, P.C.; Stidham, M.A. Potent inhibitors of acetohydroxyacid synthase. Plant Physiol. 1984, 76, 545-546. [CrossRef]

42. Subramanian, M.V.; Gerwick, B.C. Inhibition of Acetolactate Synthase by Triazolopyrimidines; ACS Symposium Series 389; ACS Publications: Washington, DC, USA, 1989; pp. 277-288.

43. Shimizu, T.; Nakayama, I.; Nakano, T.; Nezu, Y.; Abe, H. Inhibition of plant acetolactate synthase by herbicides, pyrimidinylsalicylic acids. J. Pesticide Sci. 1994, 19, 59-67. [CrossRef]

44. Henckes, J.R.; Cechin, J.; Schmitz, M.F.; Piasecki, C.; Vargas, L.; Agostinetto, D. Fitness cost and competitive ability of ryegrass susceptible and with multiple resistance to glyphosate, iodosulfuron-methyl, and pyroxsulam. Planta Daninha 2019, 37, e019197532. [CrossRef] 
45. Feng, P.C.C.; CaJacob, C.A.; Martino-Catt, S.J.; Cerny, R.E.; Elmore, G.A.; Heck, G.R.; Haung, J.; Kruger, W.M.; Malven, M.; Miklos, J.A.; et al. Glyphosate-resistant crops: Developing the next generation products. In Glyphosate Resistance in Crops and Weeds, History, Development, and Management; Nandula, V.K., Ed.; Wiley: New York, NY, USA, 2010; pp. $45-65$.

46. Green, J.M.; Castle, L.A. Transitioning from single tomultipleherbicide resistant crops. In Glyphosate Resistance in Crops and Weeds, History, Development, and Management; Nandula, V.K., Ed.; Wiley: New York, NY, USA, 2010; pp. 67-91. 